\title{
Analisis Pengaruh Ukuran Window Pada Pengendali Kemacetan di SCTP Menggunakan Fitur Multihoming
}

\author{
Agus Halid*1 ${ }^{1}$ Reza Pulungan ${ }^{2}$ \\ ${ }^{1}$ Program Studi S2/S3 Ilmu Komputer, FMIPA UGM, Yogyakarta \\ ${ }^{2}$ Jurusan Ilmu Komputer dan Elektronika, FMIPA UGM, Yogyakarta \\ e-mail: *11 agushalid@kharisma.ac.id, ${ }^{2}$ pulungan@ugm.ac.id
}

\begin{abstract}
Abstrak
Stream Control Transmission Protocol (SCTP) merupakan protokol yang mirip dengan Transmission Control Protocol (TCP) dan User Datagram Protocol (UDP). SCTP merupakan protokol yang bersifat reliable dan connectionless. Protokol ini memiliki kemampuan multistreaming dan multihoming dalam melakukan transmisi data.

Penelitian ini merupakan pemodelan terhadap SCTP menggunakan simulator OPNET yang dapat menjadi akselerasi bagi peneliti dalam bidang jaringan. SCTP pada simulator dibangun dengan melakukan modifikasi terhadap TCP. Pemodelan dimulai dengan membangun skenario jaringan dan menentukan bandwidth pada jalur yang akan dilewati oleh paket data.

Modifikasi ukuran window dalam penelitian ini menggunakan nilai 1 MMS, 2 MMS hingga 10 MMS pada pengendali kemacetan. Tujuannya adalah untuk melihat pengaruh modifikasi ukuran window terhadap nilai packet loss, delay dan throughput. Hasil pengukuran memperlihatkan bahwa nilai throughput tertinggi terdapat pada Skenario Kedua sebagaimana diperlihatkan pada Tabel 6.4 dengan nilai throughput sebesar 433.566,0244 bit/s. Penggunaan ukuran window dalam pengendali kemacetan dimaksudkan untuk menghindari banjir data pada sisi endpoint yang dapat menyebabkan packet loss.
\end{abstract}

Kata kunci-Pengendali kemacetan, throughput, delay, packet loss, ukuran window, multihoming, SCTP

\begin{abstract}
Stream Control Transmission Protocol (SCTP) is a protocol that is similar to the Transmission Control Protocol (TCP) and User Datagram Protocol (UDP). SCTP is a protocol that is both reliable and connectionless. This protocol has the ability multistreaming and multihoming in the transmit data.

This research is the modeling of the SCTP using OPNET simulator that can be accelerated for researchers in the field of networking. SCTP on the simulator was built to perform modifications to TCP. Modeling starts with building a network scenarios and determine the bandwidth on the path that will be passed by data packets.

Modification of window size in this research using $1 \mathrm{MMS}, 2 \mathrm{MMS}$ up to $10 \mathrm{MMS}$ on congestion control. The aim is to disclose the effect of modification of the window size to the value packet loss, delay and throughput. The measurement results show that the throughput rate is highest in the Second Scenario as shown in Table 6.4 with throughput value of 433.566,0244 bits/s. Using window size in congestion control is intended to prevent a flood of data on the endpoint that can lead to packet loss.
\end{abstract}

Keywords-Congestion control, throughput, delay, packet loss, window size, multihoming, SCTP 


\section{PENDAHULUAN}

$\mathrm{J}$ aringan dapat diartikan sebagai suatu sistem yang didesain untuk dapat berbagi sumber daya (resource sharing) seperti printer, processor ataupun komunikasi data (data, informasi, suara, video). Sebagaimana dipaparkan dalam [1], penambahan jumlah layanan dan aplikasi yang meluas, telah ditawarkan kepada pengguna dimanapun berada melalui akses jaringan wireless. Penambahan layanan dan aplikasi ini, tidak terlepas dari kebutuhan bandwidth dan jaminan bahwa paket yang dikirim, sampai di tujuan dalam kondisi baik. Semakin besar bandwidth maka jumlah potongan paket yang dapat ditransmisikan juga akan semakin besar. Transmisi paket yang tidak terkontrol akan menyebabkan terjadinya penumpukan paket, dan pada saat tertentu akan dimusnahkan [2]. Pemusnahan paket disebut juga dengan packet loss atau packet dropped, sehingga untuk mengurangi kejadian tersebut, perlu dilakukan pengaturan terhadap jumlah paket yang akan ditransmisikan. Pengaturan transmisi paket, dilakukan dalam pengendali kemacetan dengan menentukan ukuran window.Transmisi paket yang baru, akan dilakukan setelah pengirim memperoleh acknowledge dari penerima, jika tidak maka akan dilakukan transmisi ulang. Transmisi ulang terjadi karena paket yang dikirim dianggap tidak sampai pada tujuan. Paket dianggap sampai ditujuan bilamana pengirim menerima acknowledge dari penerima.

Penyebab lain kemacetan dalam sistem jaringan dapat dipengaruhi oleh protokol (protocol) yang digunakan. Protokol yang sering digunakan dalam jaringan yaitu Transmission Control Protocol (TCP) dan User Datagram Protocol (UDP). Fungsi utama dari protokol TCP adalah untuk menjaga reliable data, selain itu juga menjadi pengendali kemacetan dalam sistem jaringan, sehingga kemacetan yang parah dapat dihindari [3]. Protokol UDP merupakan protokol yang bersifat connectionless, di mana pengiriman data tidak memerlukan persetujuan (handshaking) sebelum dua proses saling berkomunikasi. Protokol UDP tidak menjamin suatu paket pernah dikirimkan, begitu juga dengan paket yang dibuang (packet loss) pada sisi penerima [4].

Penelitian [5] memaparkan bahwa protokol TCP merupakan protokol yang memiliki pengendali kemacetan, namun protokol UDP tidak [4], sehingga protokol ini tidak user-friendly. Penggunaan protokol UDP biasanya ditemukan pada aplikasi yang bersifat streaming. Penelitian sebelumnya, [6] juga memaparkan bahwa protokol TCP dengan menggunakan multiple TCP connection akan membutuhkan resource dalam membuka dan menutup koneksinya. Berbeda dengan SCTP yang merupakan protokol dengan kemampuan untuk melakukan transmisi data secara streaming dan memiliki pengendali kemacetan [5].

Sebagaimana dipaparkan dalam [7,8,9] bahwa pembagian beban pada SCTP menggunakan lebih dari satu jalur sumber dan tujuan yang multihomed melalui Current Multipath Transfer (CMT) bertujuan untuk meningkatkan throughput pada aplikasi jaringan. CMT merupakan pengiriman data baru secara simultan dari sumber ke tujuan melalui dua jalur atau lebih. Penelitian [9] melakukan modifikasi pengendali kemacetan dengan membagi beban menggunakan algoritma baru yang disebut dengan Split Fast Retransmit. Menurut [8] sharing buffer dapat menurunkan throughput dengan menggunakan CMT, sehingga receive buffer (rbuf) akan melakukan pemblokiran bilamana sebuah aliran didistribusikan ke sejumlah jalur end-toend oleh application layer, di sisi lain application layer penerima, memiliki ruang buffer yang terbatas. Terjadinya packet loss pada SCTP yang menyebabkan penurunan kinerja di jaringan wireless heterogen, bukan hanya disebabkan oleh Bit Error Rate (BER) yang tinggi ataupun kemacetan, sehingga dibutuhkan mekanisme untuk membedakan berbagai jenis packet loss [1].

Masalah lain yang dapat terjadi pada SCTP multihoming diantaranya adalah waktu perpindahan (transisi) antar jalur. Penelitian [10] memaparkan bahwa perpindahan jalur secara tradisional didasarkan pada jumlah pengiriman ulang timeout yang berurutan. Dasar ini dianggap tidak selalu tepat dalam SCTP multihoming. Aspek kunci optimasi dalam penelitian ini adalah waktu perpindahan antar jalur yang tersedia. Berbeda dengan penelitian yang dilakukan pada jalur yang heterogen, sebagaimana diungkapkan [11,12] bahwa dibutuhkan mekanisme yang efisien untuk meningkatkan konektivitas jaringan dan mempertahankannya.

IJCCS Vol. 9, No. 2, July 2015: $133-144$ 
Modifikasi ukuran window diawal secara signifikan mengurangi lonjakan traffic video [13]. Meskipun tidak semua hasil yang diperoleh menunjukkan pengukuran yang sama, dalam artian modifikasi ukuran window tidak menyelesaikan sama sekali masalah lonjakan traffic video. Ukuran window yang digunakan dalam penelitian ini meliputi $3^{*}$ MMS (default), $5 *$ MMS, $7 *$ MMS, $10 *$ MMS, $15 *$ MMS, dan 20*MMS.

Penggunaan pengendali kemacetan pada SCTP menurut [14], didasarkan pada ukuran Maximum Transmission Unit (MTU) dari ethernet yang digunakan. Nilai MTU yang ada saat ini adalah rata-rata 1.500 byte. Potongan data yang diijinkan tidak melebihi nilai MTU dari ethernet yang digunakan, termasuk IP header dan SCTP header. Besarnya potongan data yang kemudian dikenal dengan istilah Maksimum Segmen Size (MMS) pada penelitian sebelumnya adalah sebesar 1.460 byte. Sedangkan ukuran window diawal yang digunakan sebesar 4.380 byte.Penelitian ini akan melakukan analisa terhadap pengaruh ukuran window pada pengendali kemacetan di protokol SCTP, dimana ukuran window yang digunakan adalah $1 * \mathrm{MMS}, 2 * \mathrm{MMS}$, hingga $10 *$ MMS.

\section{METODE PENELITIAN}

Metodologi yang diterapkan dalam penelitian ini adalah :

- Mengumpulkan referensi

- Referensi tentang SCTP dikumpulkan dari tahun 2012 hingga tahun 2014, baik dari jurnal, internet maupun buku; dan

- Memilah referensi yang ada hubungannya dengan SCTP dan kemacetan dalam jaringan.

- Membangun skenario SCTP

- Menganalisa kebutuhan node yang digunakan untuk membangun SCTP pada simulator OPNET;

- Merancang arsitektur jaringan berdasarkan kebutuhan rancangan topologi. Tahap ini menempatkan node yang digunakan untuk merancang SCTP pada OPNET menggunakan Connection Node $(\mathrm{CN})$ sebagai server, Mobile Node $(\mathrm{MN})$ sebagai endpoint, Home Agen (HA) sebagai router yang mengatur informasi lokasi terakhir dari $\mathrm{MN}$, Foreign Agent (FA) merupakan router yang dikunjungi oleh $\mathrm{MN}$ dan menyediakan layanan routing kepada MN saat registrasi, dan Access Point (AP) yang menghubungkan $\mathrm{MN}$ dengan jaringan;

- Menentukan besar bandwith yang digunakan. Tahap ini merupakan penentuan besar bandwidth pada skenario yang dibuat untuk melihat nilai packet loss, delay dan throughput; dan

- Menentukan parameter yang akan diukur. Parameter yang dimaksudkan dalam penelitian ini sebagaimana terdapat dalam simulator OPNET.

- Melakukan pengukuran skenario

- Pengukuran dengan modifikasi ukuran window menggunakan bandwidth sebesar 1 Mbps; dan

- Pengukuran dengan modifikasi ukuran window menggunakan bandwidth sebesar 11 Mbps.

\section{HASIL DAN PEMBAHASAN}

Simulasi dilakukan dengan menggunakan simulator OPNET. Pengujian simulasi ini bertujuan untuk mengetahui pengaruh ukuran window pada pengendali kemacetan dengan melihat perbedaan packet loss (packet dropped), delay dan throughput pada SCTP, yang menggunakan fitur multihoming. 


\subsection{Pengujian Skenario}

Ukuran window yang digunakan sebagai nilai default adalah 1.460 byte. Nilai 1.460 byte menjadi nilai ukuran window (default) yang akan dibandingkan dengan nilai $2 *$ Maksimum Segmen Size (MSS) atau sebesar 2.920 byte. Nilai ukuran window di awal adalah 1.460 byte, sedangkan nilai ukuran window tertinggi yang digunakan adalah 14.600 byte.

\section{1.1 Skenario Pertama}

Skenario Pertama menggunakan tiga buah jalur. Ketiga jalur pada Skenario Pertama menggunakan kabel (link model) dengan nilai bandwidth masing-masing percobaan $100 \mathrm{Mbps}$ yang dihubungkan dari AP hingga ke HA. Berbeda dengan bandwidth pada AP yang menuju ke MN, nilai bandwidthnya diset dengan 11 Mbps. Secara lengkap hasil pengukuran dengan menggunakan Skenario Pertama, baik dengan menggunakan bandwidth 1 Mbps maupun 11 Mbps sebagaimana diperlihatkan pada Tabel 1 dan Tabel 2 dengan setiap percobaan dilakukan selama 60 menit atau 3.600 detik menggunakan ukuran window yang dimulai dari 1.460 byte hingga 14.600 byte.

Tabel 1 diperoleh dari hasil pengujian Skenario Pertama dengan memberikan beban bandwidth pada sisi MN sebesar 1 Mbps untuk setiap WLAN yang digunakan, dalam penelitian digunakan tiga buah WLAN yang terhubung dengan tiga buah AP. Berdasarkan Tabel 1 diperlihatkan bahwa nilai delay semakin meningkat seiring dengan peningkatan nilai ukuran window. Jumlah rata-rata packet loss sebagaimana diperlihatkan Tabel 1 sebesar 398,065778 bit/s, dan paling kecil packet loss dengan ukuran window sebesar 7.300 byte. Nilai throughput pada bagian awal dan akhir mengalami peningkatan, hal ini relevan dengan pemaparan [13], yang dalam penelitiannya melakukan modifikasi ukuran window untuk mengurangi lonjakan trafik di awal.

Tabel 1 Hasil Pengukuran Skenario Pertama (Bandwidth 1 Mbps)

\begin{tabular}{|c|c|c|c|}
\hline \multirow{2}{*}{$\begin{array}{c}\text { Ukuran } \\
\text { Window }\end{array}$} & \multicolumn{3}{|c|}{ Hasil Pengukuran } \\
\cline { 2 - 4 } & Packet Loss $(\mathrm{bit} / \mathrm{s})$ & Delay $(\mathrm{s})$ & Throughput $(\mathrm{bit} / \mathrm{s})$ \\
\hline 1.460 & 404,60444 & 0,01622 & $18.607,12000$ \\
\hline 2.920 & 409,64444 & 0,01584 & $17.636,98667$ \\
\hline 4.380 & 408,88889 & 0,01625 & $17.454,39111$ \\
\hline 5.840 & 405,77778 & 0,01633 & $16.010,02667$ \\
\hline 7.300 & 356,28444 & 0,02099 & $18.325,68000$ \\
\hline 8.760 & 413,19111 & 0,02068 & $16.956,92444$ \\
\hline 10.220 & 392,84444 & 0,02163 & $17.659,00444$ \\
\hline 11.680 & 399,47556 & 0,02434 & $16.490,48000$ \\
\hline 13.140 & 400,78222 & 0,02512 & $17.679,48444$ \\
\hline 14.600 & 389,16444 & 0,02874 & $19.535,68889$ \\
\hline
\end{tabular}

Hasil pengukuran sebagaimana diperlihatkan Tabel 2 diperoleh dengan menaikkan bandwidth MN sebesar 11 Mbps untuk setiap WLAN yang digunakan. Nilai packet loss semakin menurun seiring dengan kenaikan nilai ukuran window. Nilai bandwidth pada sisi server sangat berpengaruh pada pengiriman data menuju ke client, sehingga menyebabkan antrian paket pada sisi client, dimana pada kondisi tertentu paket tersebut akan dimusnahkan (packet loss), selain itu dapat disebabkan karena diskoneksi saat perpindahan kanal (handoff) yang berada diluar jangkauan [1]. Nilai delay mengalami kenaikan seiring dengan tingginya nilai ukuran window. Peningkatan nilai delay pada Skenario Pertama disebabkan karena jarak, antrian, jumlah node yang dilibatkan maupun transmisi ulang [15], yang pada penelitian ini peningkatan nilai delay disebabkan oleh jarak, antrian dan terjadinya transmisi ulang yang dapat diamati berdasarkan besarnya nilai packet loss pada pengukuran.

IJCCS Vol. 9, No. 2, July 2015: $133-144$ 
Tabel 2 Hasil Pengukuran Skenario Pertama (Bandwidth 11 Mbps)

\begin{tabular}{|c|c|c|c|}
\hline \multirow{2}{*}{$\begin{array}{c}\text { Ukuran } \\
\text { Window }\end{array}$} & \multicolumn{3}{|c|}{ Hasil Pengukuran } \\
\cline { 2 - 4 } & Packet Loss $(\mathrm{bit} / \mathrm{s})$ & Delay $(\mathrm{s})$ & Throughput $(\mathrm{bit} / \mathrm{s})$ \\
\hline 1.460 & 412,80889 & 0,00943 & $18.610,06667$ \\
\hline 2.920 & 417,36889 & 0,00926 & $18.611,09333$ \\
\hline 4.380 & 404,24889 & 0,00918 & $15.306,34667$ \\
\hline 5.840 & 386,51556 & 0,00978 & $16.217,04000$ \\
\hline 7.300 & 374,22222 & 0,01298 & $19.759,47556$ \\
\hline 8.760 & 412,36444 & 0,01040 & $15.288,46222$ \\
\hline 10.220 & 393,96444 & 0,01308 & $17.847,20889$ \\
\hline 11.680 & 397,83111 & 0,01436 & $18.111,41333$ \\
\hline 13.140 & 393,09333 & 0,01457 & $17.414,56000$ \\
\hline 14.600 & 390,23111 & 0,01466 & $16.488,72000$ \\
\hline
\end{tabular}

Berdasarkan pada Skenario Pertama (Tabel 1 dan Tabel 2), nilai packet loss terkecil terjadi pada nilai ukuran window 7.300 byte dengan nilai packet loss masing-masing 356,28444 bit/s dan 374,22222 bit/s. Nilai delay terkecil pada Tabel 1 terdapat pada nilai ukuran window 2.920 byte yaitu sebesar $0,015840 \mathrm{~s}(15,84 \mathrm{~ms})$, sedangkan pada Tabel 2 terdapat pada nilai ukuran window 4.380 byte yaitu sebesar $0,009184 \mathrm{~s}(9,184 \mathrm{~ms})$. Nilai throughput tertinggi pada Tabel 1 dengan ukuran window 14.600 byte yaitu sebesar 19.535,68889 bit/s, sedangkan pada Tabel 2 dengan ukuran window 7.300 byte yaitu sebesar 19.759,47556 bit/s.

\section{1.2 Skenario Kedua}

Skenario Kedua juga menggunakan tiga buah jalur, namun pada skenario ini, router dihilangkan, sehingga AP (FA) langsung dihubungkan dengan HA. Ketiga jalur pada Skenario Kedua menggunakan kabel (link model) dengan nilai bandwidth masing-masing percobaan 100 Mbps yang dihubungkan dari AP hingga ke HA. Berbeda dengan bandwidth pada AP(FA) yang menuju ke MN, nilai bandwidthnya diset dengan 11 Mbps. Secara lengkap hasil pengukuran dengan menggunakan Skenario Kedua, baik dengan menggunakan bandwidth 1 Mbps maupun 11 Mbps, sebagaimana diperlihatkan pada Tabel 3 dan Tabel 4 dengan setiap percobaan dilakukan selama 60 menit atau 3.600 detik menggunakan ukuran window yang dimulai dari 1.460 byte hingga 14.600 byte.

Hasil pengukuran sebagaimana diperlihatkan pada Tabel 3 dengan beban bandwith pada MN sebesar 1 Mbps untuk setiap WLAN yang digunakan. Berdasarkan pada Tabel 3, nilai packet loss terendah terlihat pada ukuran window 14.600 byte sebesar 250,89778 bit/s. Peningkatan ukuran window dalam pengendali kemacetan mengakibatkan packet loss pada router yang memiliki ukuran buffer kecil, atau router mengalami kemacetan [16], namun kenaikan ukuran window hanya terjadi sekali (di awal koneksi), sisanya diatur dalam mekanisme pengendali kemacetan.

Tabel 3 Hasil Pengukuran Skenario Kedua (Bandwidth $1 \mathrm{Mbps}$ )

\begin{tabular}{|c|c|c|c|}
\hline \multirow{2}{*}{$\begin{array}{c}\text { Ukuran } \\
\text { Window }\end{array}$} & \multicolumn{3}{|c|}{ Hasil Pengukuran } \\
\cline { 2 - 4 } & Packet Loss (bit/s) & Delay $(\mathrm{s})$ & Throughput $(\mathrm{bit} / \mathrm{s})$ \\
\hline 1.460 & 267,78667 & 0,01216 & $421.251,07111$ \\
\hline 2.920 & 262,50667 & 0,01182 & $376.873,15333$ \\
\hline 4.380 & 257,68000 & 0,01425 & $374.633,40444$ \\
\hline 5.840 & 259,09333 & 0,01532 & $363.822,80667$ \\
\hline 7.300 & 264,13333 & 0,01556 & $367.648,32667$ \\
\hline 8.760 & 270,14222 & 0,01837 & $390.362,00000$ \\
\hline 10.220 & 270,39111 & 0,01956 & $384.458,92222$ \\
\hline 11.680 & 262,60444 & 0,02061 & $365.538,41556$ \\
\hline 13.140 & 276,81778 & 0,02321 & $381.120,39778$ \\
\hline 14.600 & 250,89778 & 0,02615 & $419.595,21778$ \\
\hline
\end{tabular}


Nilai delay sebagaimana diperlihatkan pada Tabel 3 semakin meningkat seiring dengan peningkatan nilai ukuran window. Peningkatan delay terjadi karena protokol melakukan transmisi ulang akibat packet loss pada jaringan [15]. Berdasarkan pada hasil pengukuran (Tabel 3), nilai throughput mengalami peningkatan, selain karena bandwidth pada jaringan yang lebar (100 Mbps), juga karena jumlah node yang dilibatkan. Meskipun nilai packet loss dan nilai delay cukup tinggi, namun menurut pengamatan yang dilakukan, tingginya packet loss disebabkan jumlah data yang ditransmisikan cukup besar sehingga menyebabkan antrian yang penuh. Paket yang tidak dapat masuk kedalam antrian akan dibuang (dropped) atau dengan kata lain paket hilang (packet loss) [4].

Tabel 4 Hasil Pengukuran Skenario Kedua (Bandwidth $11 \mathrm{Mbps}$ )

\begin{tabular}{|c|c|c|c|}
\hline \multirow{2}{*}{$\begin{array}{c}\text { Ukuran } \\
\text { Window }\end{array}$} & \multicolumn{3}{|c|}{ Hasil Pengukuran } \\
\cline { 2 - 4 } & Packet Loss $(\mathrm{bit} / \mathrm{s})$ & Delay $(\mathrm{s})$ & Throughput $(\mathrm{bit} / \mathrm{s})$ \\
\hline 1.460 & 277,58222 & 0,00337 & $349.960,82667$ \\
\hline 2.920 & 262,00889 & 0,00387 & $382.106,94000$ \\
\hline 4.380 & 248,20444 & 0,00387 & $423.802,93111$ \\
\hline 5.840 & 260,40889 & 0,00447 & $391.418,23778$ \\
\hline 7.300 & 243,68000 & 0,00490 & $433.566,02444$ \\
\hline 8.760 & 251,47556 & 0,00490 & $404.192,96667$ \\
\hline 10.220 & 268,35556 & 0,00562 & $384.822,80667$ \\
\hline 11.680 & 243,44000 & 0,00592 & $410.417,51778$ \\
\hline 13.140 & 268,38222 & 0,00631 & $411.182,21778$ \\
\hline 14.600 & 278,04444 & 0,00678 & $344.030,23111$ \\
\hline
\end{tabular}

Hasil pengukuran sebagaimana diperlihatkan pada Tabel 4 diperoleh dengan beban bandwith pada MN sebesar 11 Mbps untuk setiap WLAN yang digunakan. Berdasarkan pada Tabel 4, nilai packet loss terendah terlihat pada ukuran window 11.680 byte sebesar 243,44000 bit/s. Peningkatan ukuran window dalam pengendali kemacetan mengakibatkan packet loss pada router yang memiliki ukuran buffer kecil, atau router mengalami kemacetan [16], namun kenaikan ukuran window hanya terjadi sekali (di awal koneksi), sisanya diatur dalam mekanisme pengendali kemacetan.

Nilai delay sebagaimana diperlihatkan pada Tabel 4 semakin meningkat seiring dengan peningkatan nilai ukuran window. Peningkatan delay terjadi karena protokol melakukan transmisi ulang akibat packet loss pada jaringan [15].

Berdasarkan pada hasil pengukuran (Tabel 4), nilai throughput mengalami peningkatan, selain karena bandwidth pada jaringan yang lebar (100 Mbps), juga karena jumlah node yang dilibatkan. Meskipun nilai packet loss dan nilai delay cukup tinggi, namun menurut pengamatan yang dilakukan, tingginya packet loss disebabkan jumlah data yang ditransmisikan cukup besar sehingga menyebabkan antrian yang penuh. Paket yang tidak dapat masuk kedalam antrian akan dibuang (dropped) atau dengan kata lain paket hilang (packet loss) [4].

\section{1.3 Skenario Ketiga}

Skenario Ketiga menggunakan tiga buah jalur, namun pada skenario ini, tidak lagi menggunakan link model, sehingga AP (FA) langsung dihubungkan dengan HA dengan menggunakan wireless. Ketiga jalur pada Skenario Ketiga menggunakan wireless dengan nilai bandwidth masing-masing percobaan 11 Mbps yang dihubungkan dari AP hingga ke HA. Berbeda dengan bandwidth pada AP (FA) yang menuju ke MN, nilai bandwidthnya diset dengan 11 Mbps. Secara lengkap hasil pengukuran dengan menggunakan Skenario Ketiga, baik dengan menggunakan bandwidth 1 Mbps maupun $11 \mathrm{Mbps}$, sebagaimana diperlihatkan pada Tabel 5 dan Tabel 6 dengan setiap percobaan dilakukan selama 60 menit atau 3.600 detik menggunakan ukuran window yang dimulai dari 1.460 byte hingga 14.600 byte. 
Tabel 5 Hasil Pengukuran Skenario Ketiga (Bandwidth 1 Mbps)

\begin{tabular}{|c|c|c|c|}
\hline \multirow{2}{*}{$\begin{array}{c}\text { Ukuran } \\
\text { Window }\end{array}$} & \multicolumn{3}{|c|}{ Hasil Pengukuran } \\
\cline { 2 - 4 } & Packet Loss (bit/s) & Delay $(\mathrm{s})$ & Throughput (bit/s) \\
\hline 1.460 & 251,73778 & 0,00862 & $21.989,00889$ \\
\hline 2.920 & 261,79556 & 0,00959 & $23.884,68444$ \\
\hline 4.380 & 251,74222 & 0,00784 & $16.770,82667$ \\
\hline 5.840 & 228,03111 & 0,01052 & $22.386,21778$ \\
\hline 7.300 & 251,52889 & 0,01050 & $21.460,09778$ \\
\hline 8.760 & 237,98222 & 0,01077 & $19.068,71111$ \\
\hline 10.220 & 261,35556 & 0,01029 & $17.035,91556$ \\
\hline 11.680 & 247,03556 & 0,01311 & $22.439,59556$ \\
\hline 13.140 & 239,03556 & 0,01345 & $20.560,27111$ \\
\hline 14.600 & 248,18222 & 0,01386 & $20.071,16889$ \\
\hline
\end{tabular}

Berdasarkan hasil pengukuran yang dilakukan sebagaimana diperlihatkan pada Tabel 5 dengan menggunakan Skenario Ketiga. Pengujian yang diperlihatkan pada Tabel 5 menggunakan 1 Mbps pada masing-masing WLAN MN, sedangkan pada HA dan AP (FA) menggunakan bandwidth sebesar $11 \mathrm{Mbps}$. Tabel 5 memperlihatkan bahwa packet loss tertinggi terjadi pada ukuran window 2.920 byte sebesar 261,79556 bit/s yang berbanding lurus dengan nilai throughput sebesar 23.884,68444 bit/s, dimana pada jaringan terjadi antrian yang penuh sehingga paket yang baru tiba, tidak memiliki tempat sehingga dibuang dengan kata lain packet loss [4]. Faktor yang menyebabkan perbedaan nilai packet loss diantaranya bit error pada jaringan wireless, diskoneksi pada saat terjadinya perpindahan kanal, dan kemacetan karena antrian yang berlebihan dalam jaringan [1]. Berbeda dengan nilai delay, semakin tinggi nilai ukuran window, nilai delay juga semakin tinggi sebagaimana diperlihatkan Tabel 5. Semakin besar nilai ukuran window maka semakin besar pula paket yang dapat ditransmisikan, dimana hal ini akan berpengaruh pada antrian yang terdapat dalam jaringan, sehingga berpengaruh pada transmisi ulang. Delay juga dapat disebabkan oleh node yang digunakan, dalam hal ini digunakan node yang dihubungkan dengan wireless [15]. Tingginya nilai bandwidth dalam suatu jaringan akan sulit dipertahankan apabila terdapat nilai delay, dimana paket yang ditransmisikan memiliki waktu yang telah berlalu sementara paket tersebut masih dalam perjalanan dari sumber ke tujuan [17].

Tabel 6 Hasil Pengukuran Skenario Ketiga (Bandwidth 11 Mbps)

\begin{tabular}{|c|c|c|c|}
\hline \multirow{2}{*}{$\begin{array}{c}\text { Ukuran } \\
\text { Window }\end{array}$} & \multicolumn{3}{|c|}{ Hasil Pengukuran } \\
\cline { 2 - 4 } & Packet Loss (bit/s) & Delay (s) & Throughput (bit/s) \\
\hline 1.460 & 294,90222 & 0,00279 & $19.199,86667$ \\
\hline 2.920 & 298,49333 & 0,00299 & $21.816,40889$ \\
\hline 4.380 & 303,18667 & 0,00311 & $19.458,47111$ \\
\hline 5.840 & 279,16000 & 0,00317 & $18.942,39111$ \\
\hline 7.300 & 291,58667 & 0,00334 & $19.415,44000$ \\
\hline 8.760 & 277,19556 & 0,00360 & $19.665,91111$ \\
\hline 10.220 & 287,89333 & 0,00350 & $17.510,98222$ \\
\hline 11.680 & 302,83556 & 0,00373 & $18.058,67111$ \\
\hline 13.140 & 285,16000 & 0,00406 & $19.009,36889$ \\
\hline 14.600 & 315,84000 & 0,00412 & $18.539,50667$ \\
\hline
\end{tabular}

Berdasarkan hasil pengukuran yang dilakukan sebagaimana diperlihatkan pada Tabel 6 dengan menggunakan Skenario Ketiga. Pengujian yang diperlihatkan pada Tabel 6 menggunakan 11 Mbps pada masing-masing WLAN MN, sedangkan pada HA dan AP (FA) menggunakan bandwidth sebesar $11 \mathrm{Mbps}$. Tabel 6 memperlihatkan bahwa packet loss tertinggi terjadi pada ukuran window 14.600 byte sebesar 315,84000 bit/s. Faktor yang menyebabkan perbedaan nilai packet loss diantaranya bit error pada jaringan wireless, diskoneksi pada saat 
terjadinya perpindahan kanal, dan kemacetan karena antrian yang berlebihan dalam jaringan [1]. Berbeda dengan nilai delay, semakin tinggi nilai ukuran window, nilai delay juga semakin tinggi sebagaimana diperlihatkan Tabel 6. Semakin besar nilai ukuran window maka semakin besar pula paket yang dapat ditransmisikan, dimana hal ini akan berpengaruh pada antrian yang terdapat dalam jaringan, sehingga berpengaruh pada transmisi ulang. Penyebab lain terjadinya delay adalah penggunaan node, dalam hal ini digunakan node yang dihubungkan dengan wireless [15] Tingginya nilai bandwidth dalam suatu jaringan akan sulit dipertahankan apabila terdapat nilai delay, dimana paket yang ditransmisikan memiliki waktu yang telah berlalu sementara paket tersebut masih dalam perjalanan dari sumber ke tujuan [17]. Nilai throughput tertinggi sebagaimana diperlihatkan Tabel 6 terdapat pada ukuran window 2.920 byte sebesar $21.816,40889 \mathrm{bit} / \mathrm{s}$.

\subsection{Analisis Perbandingan Hasil}

Berdasarkan pengukuran yang dilakukan pada simulator, maka tingkat packet loss terendah berada pada Skenario Ketiga dengan bandwidth WLAN MN sebesar 1 Mbps. Nilai tersebut diperoleh dari pengukuran sebagaimana diperlihatkan Tabel 5 dengan ukuran window sebesar 8.760 byte dengan nilai packet loss sebesar 237,9822222 bit/s. Secara rata-rata, nilai packet loss terendah terdapat pada Tabel 5. Sebaliknya, nilai packet loss tertinggi terlihat pada Skenario Pertama dengan bandwidth WLAN MN sebesar 1 Mbps (Tabel 1). Nilai tersebut diperoleh dari pengukuran dengan ukuran window 8.760 byte sebesar 413,1911111 bit/s. Perbandingan packet loss tertinggi dan terendah sebagaimana diperlihatkan Gambar 1.

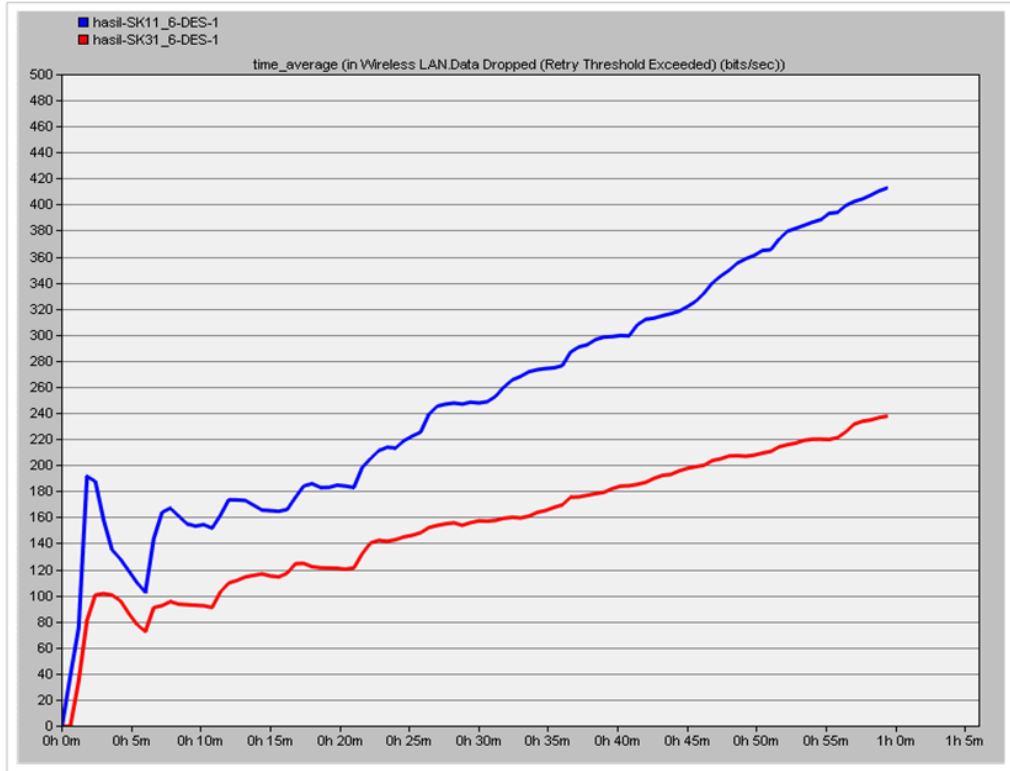

Gambar 1 Perbandingan Packet Loss

Berdasarkan pada Gambar 1 terlihat bahwa Skenario Pertama dengan bandwidth sebesar 1 Mbps percobaan 6 (SK11-6) menunjukkan nilai packet loss yang tertinggi, sebaliknya Skenario Ketiga dengan bandwidth sebesar 1 Mbps percobaan 6 (SK31-6) yang memperlihatkan nilai packet loss terendah. Tingginya packet loss pada Skenario Pertama didasarkan pada jumlah antrian yang besar pada jaringan menggunakan bandwidth 100 Mbps atau kabel sebagai link model, sehingga pada saat transmisi melalui wireless dengan bandwidth yang telah ditentukan (1 Mbps) menuju ke MN menyebabkan antrian. Perbedaan bandwidth pada kedua sisi dalam suatu jaringan akan menyebabkan antrian paket, dimana pada saat tertentu paket yang ada dalam antrian akan dibuang dengan kata lain paket hilang (packet loss) [4]. Paket hilang terjadi ketika satu atau lebih paket data transmsikan ke dalam jaringan dan mengalami kegagalan mencapai tujuannya [1].

IJCCS Vol. 9, No. 2, July 2015 : 133 - 144 
Pengukuran dengan menggunakan simulator juga memperlihatkan nilai delay tertinggi dari semua percobaan sebagaimana diperlihatkan pada Skenario Pertama (Tabel 1) dengan ukuran window 14.600 byte sebesar $0,028744 \mathrm{~s}(28,744 \mathrm{~ms})$. Nilai terendah terlihat pada Skenario Ketiga (Tabel 6) dengan ukuran window 1.460 byte sebesar 0,002795 s (2,795 ms). Perbandingan delay tertinggi dan terendah sebagaimana diperlihatkan Gambar 2.

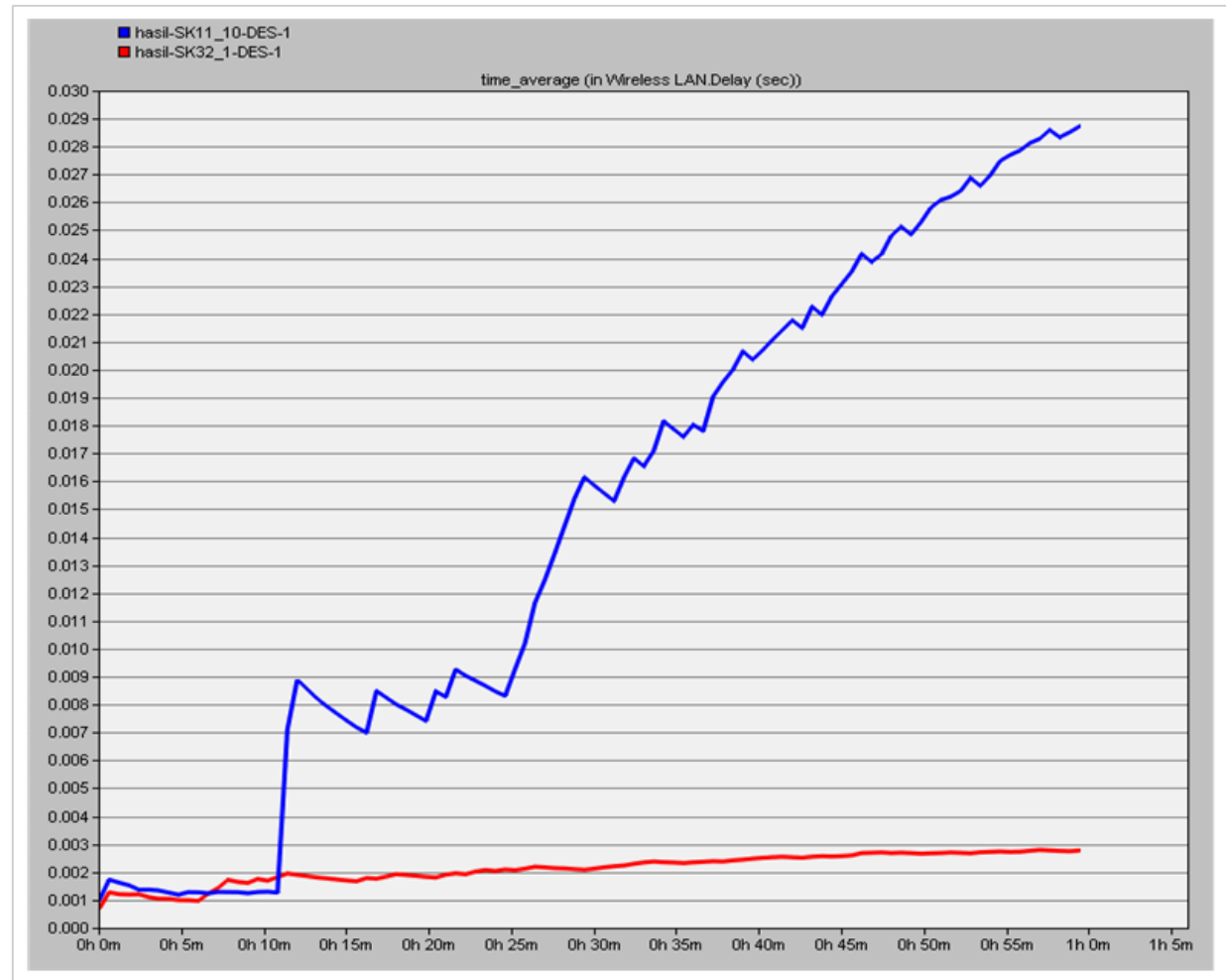

Gambar 2 Perbandingan Delay

Berdasarkan pada Gambar 2 terlihat bahwa Skenario Pertama dengan bandwidth WLAN MN sebesar 1 Mbps percobaan 10 (SK11-10) menunjukkan nilai delay yang tertinggi, sebaliknya Skenario Ketiga dengan bandwidth WLAN MN sebesar 11 Mbps percoban 1 (SK321) yang memperlihatkan nilai delay terendah. Tingginya delay pada Skenario Pertama didasarkan pada jumlah antrian ataupun node yang dilibatkan. Antrian yang panjang akan menyebabkan paket hilang dan pengendali kemacetan akan melakukan transmisi ulang. Waktu yang dibutuhkan untuk melakukan transmisi ulang merupakan salah satu penyebab delay pada jaringan komputer [15]. Begitu pula paket yang gagal mencapai tujuannya pada waktu tertentu akan ditransmisi ulang oleh pengendali kemacetan.

Hasil pengukuran yang dilakukan juga memperlihatkan bahwa nilai throughput paling tinggi terdapat pada Skenario Kedua (Tabel 4) dengan ukuran window 4.380 byte sebesar 423.802,9311 bit/s. Nilai throughput terendah pada Skenario Pertama (Tabel 2) dengan ukuran window 8.760 byte sebesar $15.288,4622$ bit/s. Perbandingan throughput tertinggi dan terendah sebagaimana diperlihatkan Gambar 3. 


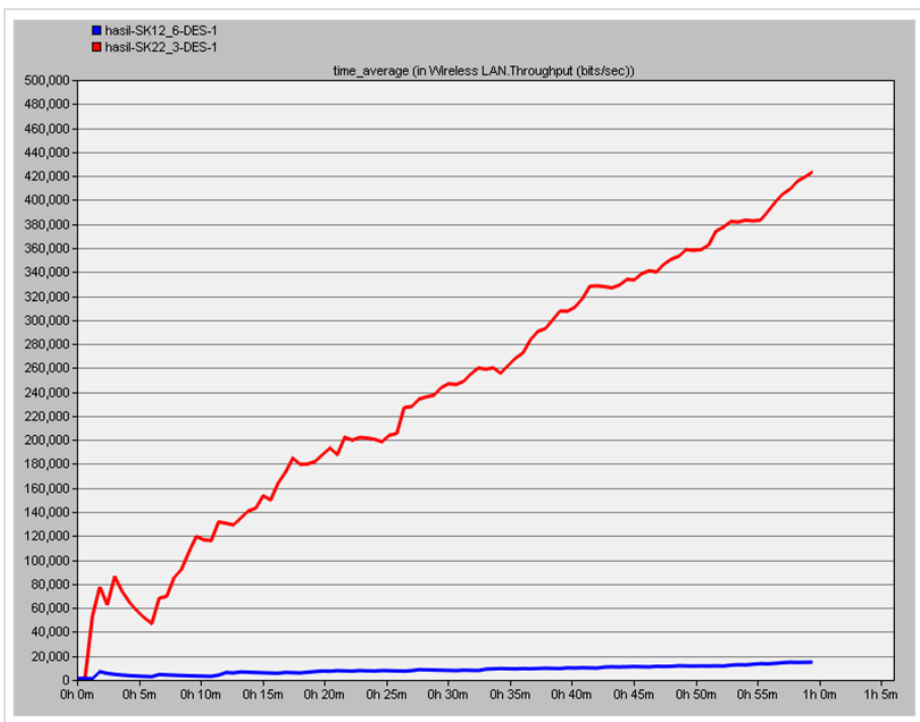

Gambar 3 Perbandingan Throughput

Berdasarkan pada Gambar 3 terlihat bahwa Skenario Kedua dengan bandwidth sebesar 11 Mbps percobaan 3 (SK22-3) menunjukkan nilai throughput yang tertinggi, sebaliknya Skenario Satu dengan bandwidth sebesar 11 Mbps percobaan 6 (SK12-6) yang memperlihatkan nilai throughput terendah. Selain karena pengaruh link model dengan bandwidth $100 \mathrm{Mbps}$ yang digunakan, tingginya throughput pada Skenario Kedua juga dipengaruhi oleh bandwidth yang ada pada WLAN MN yaitu 11 Mbps.

Secara keseluruhan, hasil pengukuran terbaik terlihat pada Skenario Kedua dengan melihat throughput dari Tabel 3 dan Tabel 4. Adapun nilai packet loss yang paling tinggi dapat disebabkan oleh berbagai faktor seperti antrian yang berlebihan karena kemacetan [1], [4], ataupun karena transmisi yang telah dikirim namun tidak pernah sampai pada jaringan yang dituju [4]. Begitu pula dengan delay yang lebih tinggi dari percobaan lain, dapat dipengaruhi oleh jarak, antrian, ataupun penggunaan node serta terjadinya transmisi ulang [15].

\section{KESIMPULAN}

Berdasarkan uraian yang telah dijelaskan pada bab sebelumnya, maka dapat ditarik kesimpulan sebagai berikut :

- SCTP fitur multihoming dapat dimodelkan pada OPNET dengan modifikasi TCP menggunakan model Mobile Node (MN), Home Agent (HA), Foreign Agent (FA) dan Correspondent Node (CN), sedangkan untuk berkomunikasi dengan Access Point (AP) yang overlap dengan AP asalnya,MN membutuhkan Agent Solicitation sebagaimana telah digunakan dalam $[18,19,20]$;

- Modifikasi ukuran window dilakukan pada pengendali kemacetan yang ada pada OPNET berdasarkan [21,16], dimana modifikasi ukuran window yang digunakan dalam penelitian ini adalah 1.460 byte ( 1 segmen), 2.920 byte ( 2 segmen) hingga 14.600 byte (10 segmen) dengan nilai MSS sebesar 1.460 byte [14]. Modifikasi ukuran window pada pengendali kemacetan berpengaruh terhadap packet loss, delay dan throughput sebagaimana diperlihatkan Tabel 1, Tabel 2, Tabel 3, Tabel 4, Tabel 5 dan Tabel 6;

- Skenario Kedua merupakan skenario yang memiliki nilai throughput yang terbaik dengan bandwidth 11 Mbps pada WLAN MN sebagaimana diperlihatkan Tabel 4, walaupun Tabel 5 dan Tabel 6 memperlihatkan nilai packet loss dan delay yang lebih rendah. Peningkatan nilai packet loss pada Skenario Kedua disebabkan karena jumlah data yang dikirimkan ke tujuan menemukan antrian yang penuh tanpa ada tempat untuk menyimpan paket yang baru, 
dalam waktu tertentu akan dibuang (dropped) atau disebut juga dengan packet loss [4]. Berbeda dengan nilai delay, selain disebabkan oleh jumlah antrian yang terdapat pada jaringan, juga karena terjadinya transmisi ulang pada link layer [15]; dan

- Berdasarkan pengukuran yang telah dilakukan, nilai packet loss, delay dan throughput, selain dipengaruhi oleh media transmisi yang digunakan juga dipengaruhi oleh jumlah node $[11,12,15]$.

\section{SARAN}

Pengembangan penelitian lebih lanjut, diberikan saran sebagai berikut :

- Pengukuran hanya dilakukan untuk melihat packet loss, delay dan throughput, sehingga untuk penelitian selanjutnya dapat menambahkan keamanan sistem jaringan sebelum melakukan pengukuran; dan

- Penelitian selanjutnya dapat melakukan pengukuran dengan membedakan penyebab terjadinya packet loss, misalnya karena antrian yang panjang atau karena jangkauan jaringan. Begitu pula dengan pengukuran delay yang dapat disebabkan oleh jarak, node yang dilibatkan atau transmisi ulang yang dilakukan oleh protokol.

\section{DAFTAR PUSTAKA}

[1] Liu, T., Xu, C., Guan, J. dan Zhang, H., 2012, Loss Detection Mechanism in SCTP Heterogeneous Wireless Networks, in Business Computing and Global Informatization (BCGIN), 2012 Second International Conference on, pp. 679-682.

[2] Tomsho, G., 2011, Guide to Networking Essentials, 6th Edition, 6th edn, Course Technology Press, Boston, MA, United States.

[3] Postel, J., 1981, Transmission Control Protocol, RFC 793 (Standard). Updated by RFCs 1122, 3168. URL: http://www.ietf.org/rfc/rfc793.txt.

[4] Kurose, J. dan Ross, K., 2013, Computer Networking: A Top-down Approach, Always learning, Pearson. URL: http://books.google.co.id/books?id=gbAhngEACAAJ

[5] Natarajan, P., Baker, F., Amer, P. D. dan Leighton, J. T., 2009, SCTP: What, Why, and How, IEEE Internet Computing 13(5), 81-85

[6] Seo, D.-W., Kim, J.-G. dan Kim, J. G., 2008, Analysis of Dynamic Congestion Control of SCTP, in Convergence and Hybrid Information Technology, 2008. ICHIT '08. International Conference on, pp. 687-693.

[7] Iyengar, J., Amer, P. dan Stewart, R., 2004, Retransmission Policies for Concurrent Multipath Transfer Using SCTP Multihoming, in Networks, 2004. (ICON 2004). Proceedings. 12th IEEE International Conference on, Vol. 2, pp. 713-719 vol.2.

[8] Liu, J., Zou, H., Dou, J. dan Gao, Y., 2008, Reducing Receive Buffer Blocking In Concurrent Multipath Transfer, in Circuits and Systems for Communications, 2008. ICCSC 2008. 4th IEEE International Conference on, pp. 367-371.

[9] Joe, I. dan Yan, S., 2009, SCTP Throughput Improvement with Best Load Sharing Based on Multihoming, in NCM, pp. 138-142. 
[10] Budzisz, L., Ferrus, R., Grinnemo, K., Brunstrom, A. dan Casadevall, F., 2007, An Analytical Estimation of the Failover Time in SCTP Multihoming Scenarios, in Wireless Communications and Networking Conference, 2007.WCNC 2007. IEEE, pp. 3929-3934.

[11] Siddiqui, F. dan Zeadally, S., 2006, SCTP multihoming support for handoffs across heterogeneous networks, in Communication Networks and Services Research Conference, 2006. CNSR 2006. Proceedings of the 4th Annual, pp. 8 pp. -250

[12] Shieh, C.-S., Lin, I.-C. dan Lai, W. K., 2008, Improvement of SCTP Performance in Vertical Handover, in ISDA (3), pp. 494-498.

[13] Eklund, J., Grinnemo, K.-J. dan Brunstrom, A., 2012, On the Use of an Increased Initial Congestion Window to Improve mSCTP Handover Performance, in AINA Workshops, pp. $1101-1106$

[14] Stewart, R., 2007, RFC4960: Stream Control Transmission Protocol. Updated by RFCs 6096,6335

[15] Welzl, M., 2005, Network Congestion Control: Managing Internet Traffic (Wiley Series on Communications Networking \& Distributed Systems), John Wiley \& Sons.

[16] Chu, H. J., Dukkipati, N., Cheng, Y. dan Mathis, M., 2013, Increasing TCP's Initial Window. URL: http://www.rfc-editor.org/rfc/rfc6928.txt

[17] Patel, S., Gupta, P. K., Garg, A., Mehrotra, P. dan Chhabra, M., 2012, Comparative Analysis of Congestion Control Algorithms Using ns-2.

[18] Perkins, C., 2002, IP Mobility Support for IPv4. [Standards Track RFC 3344]. URL: http://www.ietf.org/rfc/rfc3344.txt

[19] Perkins, C., 2010, IP Mobility Support for IPv4, Revised. [Standards Track RFC 944]. URL: http://www.ietf.org/rfc/rfc5944.txtas

[20] Jerjees, Z., 2010, Design of Interface Selection Protocols for Multi-homed Wireless Networks, Master's thesis, Brunel University, United Kingdom.

[21] Allman,M., Floyd, S. dan Partridge, C., 2002, Increasing TCP's Initial Window, RFC 3390 (Proposed Standard). URL: http://www.ietf.org/rfc/rfc3390.txt 